\title{
Burden of chickenpox on families: A study in Quebec
}

\author{
Philippe De Wals MD PhD ${ }^{1,2,3}$, Manon Blackburn MD MSc ${ }^{3}$, Maryse Guay MD MSc ${ }^{1,3}$, Gina Bravo PhD ${ }^{1,4}$, \\ Danièle Blanchette $\mathrm{MSc}^{5}$, Monique Douville-Fradet $\mathrm{MD} \mathrm{MHSc}^{6}$
}

\begin{abstract}
P De Wals, M Blackburn, M Guay, G Bravo, D Blanchette, M Douville-Fradet. Burden of chickenpox on families: A study in Quebec. Can J Infect Dis 2001;12(1):27-32.

OBJECTIVE: To estimate the nonhospital costs of treating chickenpox and to ascertain the opinion of parents regarding the usefulness of vaccination.

DESIGN: Retrospective postal survey.

SETTING: Province of Quebec.

PARTICIPANTS: Random sample of 3333 families with children aged six months to 12 years.

OUTCOME MEASURES: For cases of chickenpox that occurred between September 1, 1997 and August 31, 1998, the use of health services, time away from school or work, patient care required, direct and indirect costs for the families and the health care system, and the opinion of parents regarding chickenpox and the vaccine were evaluated.

RESULTS: The response rate was $64.7 \%$, and $18.8 \%$ of households reported a history of chickenpox, a total of 693 cases. A physician was consulted in $45.8 \%$ of these cases, and medication was used in $91.7 \%$. The frequency of hospitalizations was $0.6 \%$. Time away from work or school caused by the disease was 4.1 days on average, with $46.5 \%$ of absences being attributed to the risk of contagion. The total average cost of a case of chickenpox was $\$ 225$. Direct expenses for households accounted for $11 \%$ of the total cost, public sector direct costs $7 \%$, indirect costs related to absence from work $38 \%$ and caregiving time $45 \%$. A majority of parents $(70 \%)$ were in favour of a systematic childhood immunization program. CONCLUSIONS: Chickenpox without complications is disruptive for families, but the direct costs for families and the public sector are relatively small.
\end{abstract}

Key Words: Chickenpox; Cost; Vaccine; Varicella; Immunization

\section{Fardeau de la varicelle pour les familles : Étude québécoise}

OBJECTIF : Estimer les coûts non hospitaliers du traitement de la varicelle et obtenir l'opinion des parents au sujet de l'utilité de la vaccination.

MODÈLE : Enquête postale rétrospective.

CONTEXTE : Province de Québec.

PARTICIPANTS : Échantillon aléatoire de 3333 familles ayant des enfants de six mois à 12 ans.

MESURES PARAMÉTRIQUES : Dans les cas de varicelle qui sont survenus entre le $1^{\text {er }}$ septembre 1997 et le 31 août 1998, l'utilisation des services de santé, l'absentéisme à l'école ou au travail, les soins aux patients, les coûts directs et indirects pour les familles et pour le système de soins de santé et l'opinion des parents au sujet de la varicelle et de son vaccin ont été évalués.

voir page suivante

\footnotetext{
${ }^{1}$ Département des sciences de la santé communautaire, Université de Sherbrooke, Sherbrooke, Québec; ${ }^{2}$ Centre de recherche clinique du Centre universitaire de santé de l'Estrie, Sherbrooke; ${ }^{3}$ Direction de la santé publique, de la planification et de l'évaluation de la Régie régionale de la santé et des services sociaux de la Montérégie, Longueuil, Québec; ${ }^{4}$ Centre de recherche en gérontologie et gériatrie de l'Institut universitaire de gériatrie de Sherbrooke, Sherbrooke, Québec; ${ }^{5}$ Faculté d'Administration de l'Université de Sherbrooke, Sherbrooke, Québec; ${ }^{6}$ Ministère de la Santé et des Services sociaux du Québec, Québec, Québec

Correspondence and reprints: Dr Philippe De Wals, Département des sciences de la santé communautaire, Université de Sherbrooke, 3001 12th Avenue North, Sherbrooke, Québec J1H 5N4. Telephone 819-564-5348,fax 819-564-5397, e-mail pdewals@courrier.usherb.ca Received for publication January 24, 2000. Accepted May 5, 2000
} 
RÉSULTATS : Le taux de réponse a été de 64,7\%, et 18,8\% des foyers ont signalé des cas de varicelle, soit en tout, 693 cas. Un médecin a été consulté dans $45,8 \%$ de ces cas et un médicament a été utilisé dans $91,7 \%$. La fréquence des hospitalisations a été de 0,6\%. L'absentéisme au travail causé par la maladie a été de 4,1 jours en moyenne, 46,5\% des absences ayant été attribuées au risque de contagion. Le coût moyen total d'un cas de varicelle a été de 225 \$. Les dépenses directes pour les foyers représentaient $11 \%$ du coût total. Les coûts directs imputés au secteur public ont été de $7 \%$. Les coûts indirects associés à l'absentéisme au travail ont représenté 38 \% et le temps consacré à la prestation des soins à 45 $\%$. Une majorité des parents (70\%) étaient en faveur d'un programme d'immunisation infantile systématique. CONCLUSIONS : La varicelle sans complication perturbe les familles, mais les coûts directs assumés par les familles et le secteur public sont relativement restreints.

$\mathrm{V}$ aricella vaccine was licensed in Canada in December 1998 (1). To evaluate the appropriateness of a publicly funded, childhood immunization program, a representative sample of Quebec families was surveyed to estimate the direct and indirect costs of the nonhospital treatment of chickenpox. The results of economic analyses completed in other countries $(2-13)$ cannot be extrapolated to Canada because of differences in the composition of families, natural caregivers, employment rate, income and the cost of health services. Furthermore, exchange rates do not accurately reflect real differences in buying power. We also thought it was important to ascertain people's opinions about the disruptions caused by chickenpox and whether people would support the introduction of an immunization program.

\section{DATA AND METHODS}

The study was based on a questionnaire given to a representative sample of 3333 Quebec families with at least one child between six months and 12.5 years of age. The families were identified from the file on children covered by the provincial health insurance plan (Régie de l'Assurance-Maladie du Québec [RAMQ]); it was stratified proportionally by year of birth. The sample size was calculated to obtain an accuracy of $2 \%$ in estimates of proportions among households, assuming a response rate of $60 \%$. The first mailing (introduction letter and questionnaire) was sent in the first week of September 1998. A reminder was sent one week later, and a second questionnaire was sent three weeks later. The study protocol was approved by the Ethics Committee of the Centre universitaire de santé de l'Estrie and the Commission d'accès à l'information du Québec, Québec, Québec.

The adult most involved in the children's education and care was asked to complete the questionnaire. Section 1 related to the composition of the household, including children in joint custody arrangements. Section 2 asked about cases of chickenpox that occurred between September 1, 1997 and August 31, 1998. A profile had to be completed for each case of chickenpox; the profile comprised information on medical consultations and medications, possible complications, and absence from school or work, specifying whether the absence was because the person was sick or because of the risk of contagion. The next section asked about the costs incurred with regards to all cases of chickenpox that occurred in the household, and information on outside help, paid or not; travel for medical consultations; money spent on medications; time spent looking after the patients; and time off from work to do so. Section 4 asked the parents' opinion about the seriousness of chickenpox, how disruptive it is and its financial impact, and whether they would support a systematic immunization program that would involve the administration of an additional vaccine. Section 5 of the questionnaire covered sociodemographic information.

The evaluation of the costs of the disease was based on the principle of human capital and from a societal perspective. Using this approach, all the resources used to care for sick persons constituted direct costs. Indirect costs were caregiving time costs and productivity loss associated with absence from work. The costs were broken down according to whether they were actual expenditures and whether they were borne by the families or the public sector. Intangible costs, such as fatigue, anxiety and interpersonal tensions caused by the disease, were not taken into account.

For each household that had a history of chickenpox during the previous year, a total cost was calculated (in $1998 \mathrm{Ca}$ nadian dollars). To take into account unequal sampling probability, the observations were weighted by the inverse of the number of children aged 12 years or younger. Because the cost distributions were not normal, the mean and median values were calculated, together with the semi-interquartile intervals (the difference between the values of the 75 th and 25 th percentiles of the distribution).

Costs for the households were travel expenses to see the doctor, either in a personal car (based on an average cost of $\$ 0.35 / \mathrm{km}$ established by the Canadian Automobile Association) or by public transport, the total amount spent on medications and babysitting expenses. RAMQ fee scales were used to estimate the cost of medical consultations, namely $\$ 29.30$ for general practitioners and $\$ 28.30$ for paediatricians. For calls to a helpline, an estimate of the average cost of a call to InfoSanté (\$11.51), established by the Ministère de la Santé et des Services sociaux du Québec, was used.

Productivity costs were calculated by multiplying the time taken from work by an hourly wage. The respondent and his or her spouse were asked whether they had a job and, if so, their gross hourly wage, the number of hours of work per week, and the number of hours and days that they remained off of work to look after the sick person(s). For individuals aged 18 years or older who reported an absence due to chickenpox, it was assumed that they had a full-time job ( $7 \mathrm{~h} /$ day) and were paid at the average wage rate in Quebec $(\$ 14.14 / \mathrm{h})$.

The study also took into account the replacement cost for the time, outside working hours, that parents spent with the sick people. The respondents were asked how many hours or days that they spent caretaking, and a maximum of $4 \mathrm{~h}$ of 
TABLE 1

Frequency of health services use and complications for chickenpox cases by age group in Quebec from September 1, 1997 to August 31, 1998

\begin{tabular}{lcccc}
\hline & \multicolumn{4}{c}{ Age group } \\
$\begin{array}{l}\text { Health service used } \\
\text { or complication }\end{array}$ & $\begin{array}{c}\text { Birth to } \\
\text { 4 years }\end{array}$ & $\begin{array}{c}\mathbf{5} \text { to } \\
\mathbf{1 7} \text { years }\end{array}$ & $\begin{array}{c}\mathbf{1 8} \text { years and } \\
\text { older }\end{array}$ & $\begin{array}{c}\text { All } \\
\text { ages }\end{array}$ \\
\hline $\begin{array}{l}\text { Visits to general } \\
\text { practitioners (\%) }\end{array}$ & 32.8 & 43.2 & 62.5 & 38.0 \\
$\begin{array}{l}\text { Visits to paediatricians } \\
\text { (\%) }\end{array}$ & 19.7 & 10.3 & - & 15.4 \\
$\begin{array}{l}\text { Nonprescription } \\
\text { medications (\%) }\end{array}$ & 91.8 & 91.1 & 75.0 & 91.7 \\
$\begin{array}{l}\text { Prescription } \\
\text { medications (\%) }\end{array}$ & 6.0 & 6.2 & 50.0 & 6.8 \\
$\begin{array}{l}\text { Hospitalizations (\%) } \\
\text { Scars (\%) }\end{array}$ & 0.6 & 0.7 & - & 0.6 \\
\hline
\end{tabular}

care/day was assumed, at a replacement cost equal to the minimum wage in Quebec in 1998 (\$6.80/h). To avoid counting the same time twice, this latter calculation was not performed for the days of care that coincided with the days off of work.

Parents' opinions regarding chickenpox and the vaccine were measured using 5-point Likert-type scales. Bivariate analyses were completed to identify the differences in opinion between different sociodemographic categories using the ${ }^{2}$ test.

\section{RESULTS}

Participation: After eliminating duplicates, the questionnaire was sent to 3308 parents, and 2140 replies were received $(64.7 \%)$. Twelve respondents said there was no child aged 12 years or younger in the household and were excluded from the study. The vast majority (94.9\%) of the respondents were women, and the median age was 35 years, ranging from 15 to 59 years. The total number of individuals in the households varied from two to 11 , with a median of four. The median number of children aged 12 years and younger was two, ranging between one and seven.

Incidence of chickenpox and use of health services: A history of chickenpox was reported by 400 households $(18.8 \%$ of the total). For 181 households, this involved a single case and for the others, more than one case. The median age of the 693 people with chickenpox was four years, and $90 \%$ of the cases occurred in children under 10 years of age.

The frequency of the use of health services and complications is given in Table 1. A physician was consulted in $45.8 \%$ of the cases, namely a general practitioner in $38.0 \%$ of the cases and a paediatrician in $15.4 \%$ (in $7.6 \%$ of the cases, both categories of physicians were consulted). Consultations tended to be more frequent among adults. The great majority of patients $(91.7 \%)$ used nonprescription medications, and a small number $(6.8 \%)$ used prescription medications. The most common medications used were topical antipruritics $(81.9 \%$ of the cases), antipyretics (62.3\%) and oral antipruritics (40.7\%). Oral antibiotics were prescribed for $2.1 \%$ of patients. Only one patient reported receiving antiviral medication. In the sample,
TABLE 2

Average number of days of absence from work or school of chickenpox sufferers by age group in Quebec from September 1, 1997 to August 31, 1998

\begin{tabular}{|c|c|c|c|c|}
\hline & \multicolumn{4}{|c|}{ Age group } \\
\hline & $\begin{array}{l}\text { Birth to } \\
4 \text { years }\end{array}$ & $\begin{array}{c}5 \text { to } \\
17 \text { years }\end{array}$ & $\begin{array}{c}18 \text { years and } \\
\text { older }\end{array}$ & $\begin{array}{c}\text { All } \\
\text { ages }\end{array}$ \\
\hline $\begin{array}{l}\text { Absence } \\
\text { because sick }\end{array}$ & 0.9 & 1.9 & 2.4 & 2.2 \\
\hline $\begin{array}{l}\text { Absence } \\
\text { because } \\
\text { contagious }\end{array}$ & 0.8 & 1.6 & 2.9 & 1.9 \\
\hline Total absences & 1.8 & 3.5 & 5.3 & 4.1 \\
\hline
\end{tabular}

four patients were reported as having complications that led to hospitalization $(0.6 \%$ of the cases): high fever in three people and a skin infection in a fourth.

Duration and causes of time off of daycare, school or work: For people with chickenpox, the total number of days of absence from daycare, school or work was 4.1 days on average, with a maximum of 55 days. The amount of time missed increased with age (Table 2). It was estimated that $53.5 \%$ of the absences was attributable to the sickness itself and $46.5 \%$ to the risk of contagion.

For households with a history of chickenpox, the respondents reported an absence to look after one or more affected individuals in $24.5 \%$ of the cases and of their spouse in $9.9 \%$. In $43.2 \%$ of the cases, the absences were one day or less, with one extreme case lasting 30 days. On average, the absence lasted 0.7 days for the respondents and 0.2 days for their spouses.

Nonhospital costs: The distribution of nonhospital costs per household is given in Table 3. A little less than half (42.2\%) of the households incurred travel expenses for medical consultations, but this category of expenses was a minor component of the total cost. The vast majority (95.4\%) of the respondents purchased medications, at an average cost of $\$ 20.90$. Costs for the services of a babysitter at home were infrequent $(9.7 \%$ of the households). One notable exception was that there were seven cases of chickenpox in a family of eight, which generated expenses of $\$ 4,000$. Helpline services were frequently used (37.5\% of households), but the related costs were much less than those for medical visits ( $\$ 4.35$ on average versus $\$ 19.88$ ). Absence from work of the patients was infrequent $(1.9 \%$ of households), which reflects the rarity of this disease among adults. Absence from work of the primary caregivers, however, was much more common and was reported by $26.4 \%$ of the households. There was great variability in the costs associated with the time spent caregiving, which accounted for nearly half (45\%) of the average total costs.

The distribution of nonhospital costs per case of chickenpox is shown in Table 4. For all age categories combined, the average total unit cost was $\$ 224.50$. Direct expenses for households accounted for $11 \%$ of this total, public sector expenses $7 \%$, productivity costs $38 \%$ and caregiving time costs $45 \%$. The cost associated with chickenpox increased with age, from less than $\$ 200$ for a young child to nearly $\$ 700$ for an 
TABLE 3

Nonhospital costs associated with a history of chickenpox for households that had at least one case of chickenpox in Quebec from September 1, 1997 to August 31, 1998

\begin{tabular}{|c|c|c|c|c|c|}
\hline Nonhospital costs & $\begin{array}{l}\% \text { of households with } \\
\text { costs }(n=400)\end{array}$ & $\begin{array}{l}\text { Median } \\
\text { cost }(\$)\end{array}$ & $\begin{array}{l}\text { Maximum } \\
\text { cost }(\$)\end{array}$ & $\begin{array}{c}\text { Semi-interquartile } \\
\text { interval }\end{array}$ & $\begin{array}{l}\text { Average } \\
\text { cost }(\$)\end{array}$ \\
\hline \multicolumn{6}{|l|}{ Household expenditures } \\
\hline Public transport & 1.9 & 0.00 & 60.00 & 0.00 & 0.39 \\
\hline Medications purchased & 95.4 & 15.00 & 360.00 & 6.00 & 20.90 \\
\hline Babysitting & 9.7 & 0.00 & 4000.00 & 0.00 & 13.75 \\
\hline Visits to general practitioners & 41.2 & 0.00 & 117.20 & 0.00 & 15.03 \\
\hline Visits to paediatricians & 14.4 & 0.00 & 113.20 & 0.00 & 4.85 \\
\hline Calls to Info-Santé & 37.5 & 0.00 & 11.51 & 0.00 & 4.35 \\
\hline Total public sector expenditures & 65.7 & 11.51 & 184.31 & 19.91 & 24.23 \\
\hline \multicolumn{6}{|l|}{ Productivity costs } \\
\hline Caregiving time costs & 93.0 & 136.00 & 1305.60 & 55.76 & 155.65 \\
\hline Total & 100.0 & 210.15 & 8306.61 & 124.90 & 349.59 \\
\hline Total excluding caregiving time costs & 98.1 & 51.90 & 8306.61 & 64.71 & 193.94 \\
\hline
\end{tabular}

TABLE 4

Average nonhospital costs for a case of chickenpox by age group in Quebec from September 1, 1997 to August 31,1998

\begin{tabular}{|c|c|c|c|c|}
\hline \multicolumn{5}{|c|}{ Age group } \\
\hline Nonhospital costs & Birth to 4 years $(\$)$ & 5 to 17 years $(\$)$ & 18 years and older $(\$)$ & All ages (\$) \\
\hline \multicolumn{5}{|l|}{ Household expenditures } \\
\hline Public transport & 0.37 & 0.11 & 0.00 & 0.25 \\
\hline Medications purchased & 12.72 & 14.11 & 16.91 & 13.42 \\
\hline Babysitting & 6.07 & 9.89 & 52.77 & 8.83 \\
\hline \multicolumn{5}{|l|}{ Public sector expenditures } \\
\hline Visits to general practitioners & 8.82 & 10.76 & 8.47 & 9.65 \\
\hline Visits to paediatricians & 4.60 & 1.43 & 0.00 & 3.11 \\
\hline Calls to Info-Santé & 2.99 & 2.27 & 7.89 & 2.79 \\
\hline Total public sector expenditures & 16.41 & 14.46 & 16.36 & 15.55 \\
\hline Caregiving time costs & 102.88 & 95.68 & 111.11 & 99.96 \\
\hline Total & 198.20 & 232.47 & 681.35 & 224.50 \\
\hline Total excluding caregiving time costs & 95.32 & 136.79 & 570.24 & 124.50 \\
\hline
\end{tabular}

adult. These variations were mainly attributable to indirect costs, primarily the absence from work of adult patients.

Opinion of parents: Most parents considered chickenpox to be a mild disease. Only a small minority $(6.4 \%)$ thought that the infection was often or very often serious for the child. The perception of the seriousness of the disease was more common in lower income groups $(\mathrm{P}<0.001)$, and this fear was significantly more widespread among people under 25 years of age
$(\mathrm{P}<0.001)$ and those who had not finished college $(\mathrm{P}<0.001)$. Opinions regarding how disruptive the disease varied greatly, with the most educated respondents $(\mathrm{P}<0.001)$ considering chickenpox as being more disruptive. A small percentage of parents $(9.2 \%)$ thought that the financial cost of the disease was very or quite high, and this perception was more common among young people $(\mathrm{P}<0.001)$ and those whose household income was less than $\$ 40,000(\mathrm{P}<0.001)$. 
A majority of parents were in favour of a systematic childhood immunization program. For example, $70 \%$ of the respondents responded that the vaccine was a very good, good or reasonably good solution. Only $8 \%$ of respondents were completely opposed to the vaccine. Favourable opinions were more common among the youngest respondents $(\mathrm{P}<0.001)$, those with the least education $(\mathrm{P}<0.001)$ and lowest income $(\mathrm{P}<0.001)$, and those from single-parent families $(\mathrm{P}<0.001)$. The distribution of opinions was not changed much by the information that an additional injection might be required. The percentage of support for systematic immunization dropped to $64 \%$, and the percentage of people completely opposed to the vaccine went up to just over $10 \%$.

\section{DISCUSSION}

The objectives of the study were to estimate the nonhospital costs of treating chickenpox and to ascertain the opinion of parents regarding the usefulness of vaccination from a representative sample of families in Quebec. Information on varicella cases that occurred within a 12-month period was collected retrospectively. The predictive value of a history of varicella is generally good $(14,15)$, and although the retrospective nature of the survey may have led to some inaccuracy in the information reported, there is no reason to believe that a systematic bias is present. Despite the high response rate $(64.7 \%)$, it may be suspected that the respondents tend to come from families from a higher socioeconomic level than the nonrespondents, which may result in overestimation of the direct and indirect costs. The distribution of opinions about immunization may vary between provinces in Canada, and care should be taken in extrapolating the results of the present study.

In a population where the large majority of people is in good health, complications from chickenpox are relatively rare. Oral antibiotics were prescribed in only $2.1 \%$ of the cases, and the disease resulted in hospitalization in only $0.6 \%$ of the cases. These figures are very similar to those reported in a telephone survey of parents of children under 13 years of age completed in the United States: $2.7 \%$ of the patients were treated with antibiotics and $0.5 \%$ were hospitalized (16). Better education of parents in diagnosing and managing chickenpox without complications may reduce the number of medical consultations, which occurred in about half of the cases in our survey. A significant percentage of households (37.5\%) called a helpline. This use of a source of inexpensive advice may become even more frequent and replace medical visits. For the great majority of chickenpox cases, advice given over the telephone by a nurse and the use of over-the-counter drugs constitute adequate treatment.

Nearly half the time missed at daycare, school or work by patients is explained by exclusion policies in daycare centres and schools. Recently, the Canadian Paediatric Society recommended that children should return to school as soon as their health permits (17). We will have to wait to see if this practice is really followed. In a survey conducted in the Sherbrooke area in 1997, only a minority of educators (four of 22) said they were unreservedly willing to accept contagious children, if there were a recommendation to do so (18). It may also be diffi- cult for a parent to evaluate the ability of a convalescent child to participate in regular daycare centre or school activities.

The average total cost estimated for school-aged children in our study ( $\$ 232$ ) is similar to that calculated by Law et al (19) (\$236). For children under age five years, we arrived at a much lower cost (\$198 versus $\$ 370$ ). In this latter study, chickenpox cases were actively recruited in daycare centres, doctors' offices and schools in towns with a university paediatric centre, and the cost calculations related to caregiving time were based on the parents' actual salary, which may explain the difference.

The largest components in the total cost of chickenpox were absence from work and the time devoted to care. There is no consensus regarding assigning a market value to the time a parent devotes to a sick child. There is also no certainty that brief absences from work result in a significant drop in productivity. This may be true in assembly line work, but in many types of jobs, workers have some latitude in executing their tasks and can compensate for an absence of one day or less by temporarily increasing their productivity. The direct expenses for the families and the public sector totalled only $\$ 40$ on average. A publicly funded immunization program would benefit mainly families, who would thus avoid all of the disruptions caused by the disease as well as the health care expenses ( $\$ 25 /$ case on average). For the public sector, the potential savings per case prevented would be about $\$ 15$, much less than the current cost of the vaccine and its administration.

A favourable attitude exists toward the varicella vaccine, even if immunization requires an additional injection. Only a small minority said that they were opposed to vaccination. In the higher level socioeconomic groups, chickenpox is viewed mainly as a nuisance. Conversely, in the lower socioeconomic groups, chickenpox is seen as a relatively serious and costly disease. The latter groups (young parents, single parents, low income parents and those with limited education) are the ones who are most in favour of vaccination. When living conditions are fragile, any disruption caused by a disease, even a mild disease, is difficult to handle. A publicly funded, varicella immunization program may, therefore, be considered an example of an intervention designed to reduce social inequities.

\section{CONCLUSIONS}

The present survey estimated the burden of chickenpox. From a societal viewpoint, most of the nonhospital costs of the disease relate to parents' absence from work and the time that they devoted to the patients with chickenpox. The direct expenses for the households and the public sector were relatively small (about $\$ 40 /$ case). To obtain a more complete evaluation of the usefulness of a varicella immunization program, the serious complications resulting in hospitalization, and possibly some deaths (20), should be taken into account.

ACKNOWLEDGEMENTS: This study was supported by a grant from the Direction générale de la santé publique du ministère de la Santé et des Services sociaux du Québec. The grant was recognized by the Fonds de la recherche en santé du Québec (No 981106). 


\section{REFERENCES}

1. National Advisory Committee on Immunization. Statement on recommended use of varicella virus vaccine. Can Commun Dis Rep 1999;25(ASC-1):1-16.

2. Preblud SR, Orenstein WA, Koplan JP, Bart KJ, Hinman AR. A benefit-cost analysis of a childhood varicella vaccination program. Postgrad Med J 1985;61(Suppl):17-22.

3. Preblud SR. Varicella: Complications and costs. Pediatrics 1986;78:728-35.

4. Huse DM, Meissner HC, Lacey MJ, Oster G. Childhood vaccination against chickenpox: an analysis of benefits and costs. J Pediatr 1994;124:869-74.

5. Lieu TA, Black SB, Rieser N, Ray P, Lewis EM, Shinefield HR. The cost of childhood chickenpox: parents' perspective. Pediatr Infect Dis J 1994;13:173-7.

6. Lieu TA, Cochi SL, Black SB, et al. Cost-effectiveness of a routine varicella vaccination program for US children. JAMA 1994;271:375-81.

7. Beutels P, Clara R, Tormans G, Van Doorslaer E, Van Damme P. Costs and benefits of routine varicella vaccination in German children. J Infect Dis 1996;174(Suppl 3):S335-41.

8. Strassels SA, Sullivan SD. Clinical and economic considerations of vaccination against varicella. Pharmacotherapy 1997;17:133-9.

9. Ferson MJ, Shen WL, Stark A. Direct and indirect costs of chickenpox in young children. J Paediatr Child Health 1998;34:18-21.

10. Saddier P, Floret D, Guess HA, et al. Cost of varicella in France: A study in day-care centers. J Infect Dis 1998;178(Suppl 1):S58-63.

11. Coudeville L, Paree F, Lebrun T, Sailly JC. The value of varicella vaccination in healthy children: cost-benefit analysis of the situation in France. Vaccine 1999;17:142-51.
12. Diez Domingo J, Ridao M, Latour J, Ballester A, Morant A. A cost benefit analysis of routine varicella vaccination in Spain. Vaccine 1999;17:1306-11.

13. Scuffham P, Devlin N, Eberhartt-Phillips J, Wilson-Salt R. The cost-effectiveness of introducing a varicella vaccine to the New Zealand immunisation schedule. Soc Sci Med 1999;49:763-79.

14. Steele RW, Coleman MA, Fiser M, Bradsher RW. Varicella zoster in hospital personnel: Skin test reactivity to monitor susceptibility. Pediatrics 1982;70:604-8.

15. Lieu TA, Black SB, Takahashi $\mathrm{H}$, et al. Varicella serology among school age children with a negative or uncertain history of chickenpox. Pediatr Infect Dis J 1998;17:120-5.

16. Yawn BP, Yawn RA, Lydick E. The relative community burden of otitis media and varicella. Clin Ther 1996;18:877-86.

17. Infectious Diseases and Immunization Committee, The Canadian Pediatric Society. School and daycare exclusion policies for chickenpox: A rational approach. Can J Infect Dis 1999;10:196-8.

18. Garant D, Gauthier P, Robitaille O, Sarrazin J. Enquête sur la varicelle. Rapport de stage en santé communautaire. Sherbrooke: Département des Sciences de la santé communautaire, Faculté de médecine, Université de Sherbrooke, 1997.

19. Law B, Fitzsimon C, Ford-Jones L, et al. Cost of chickenpox in Canada: Part I. Cost of uncomplicated cases. Pediatrics 1999;104:1-6.

20. Law B, Fitzsimon C, Ford-Jones L, McCormick J, Rivière M. Cost of chickenpox in Canada: Part II. Cost of complicated cases and total economic impact. Pediatrics 1999;104:7-14. 


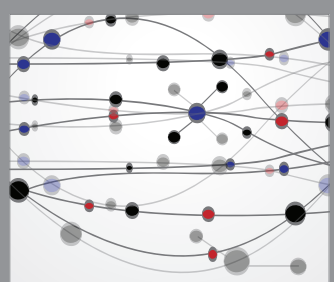

The Scientific World Journal
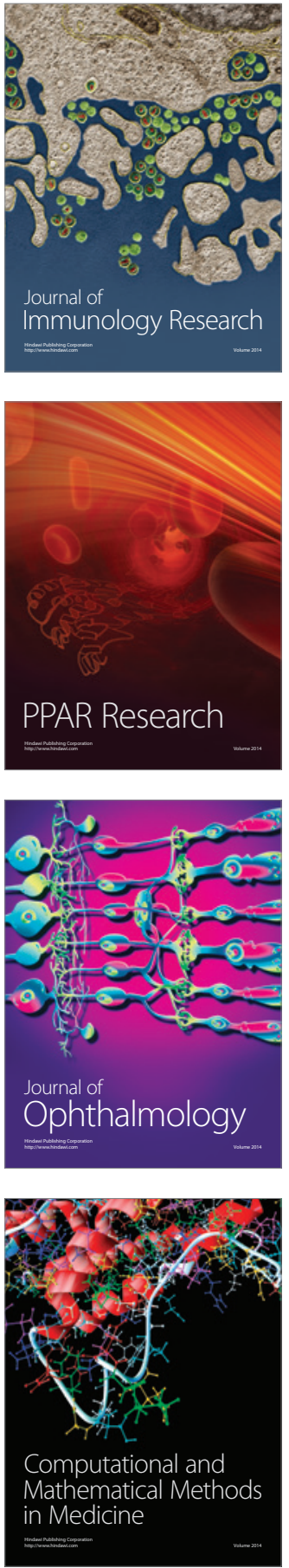

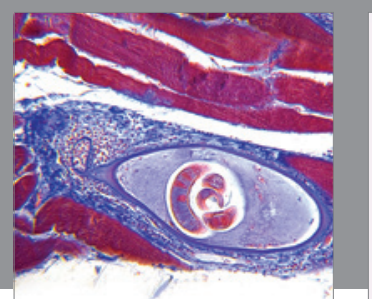

Gastroenterology Research and Practice

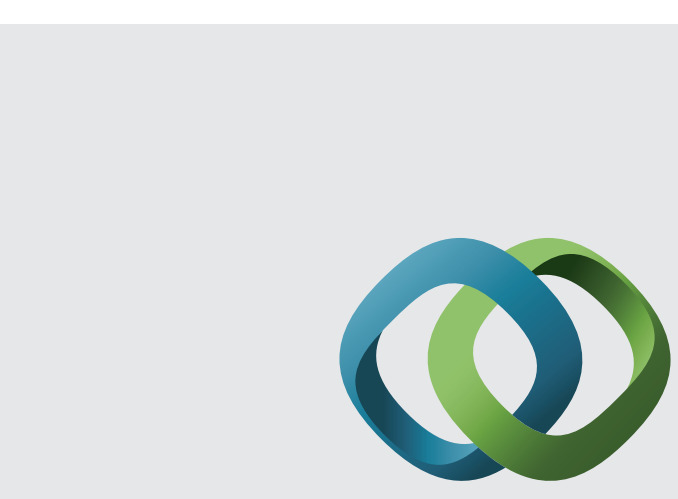

\section{Hindawi}

Submit your manuscripts at

http://www.hindawi.com
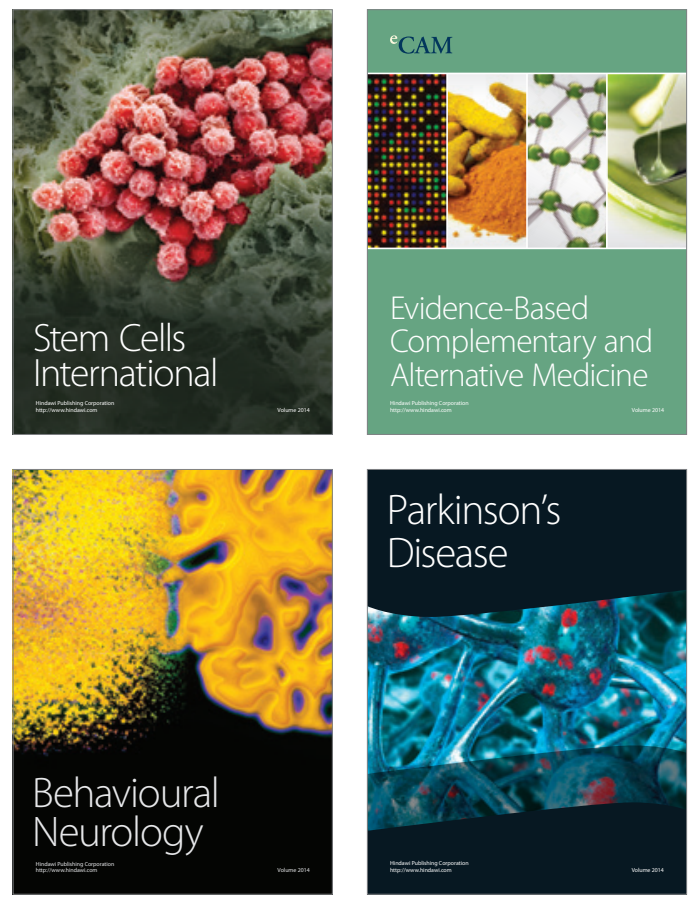
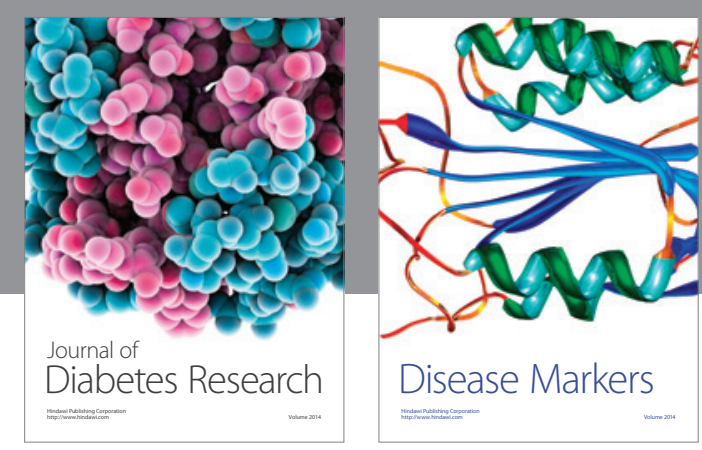

Disease Markers
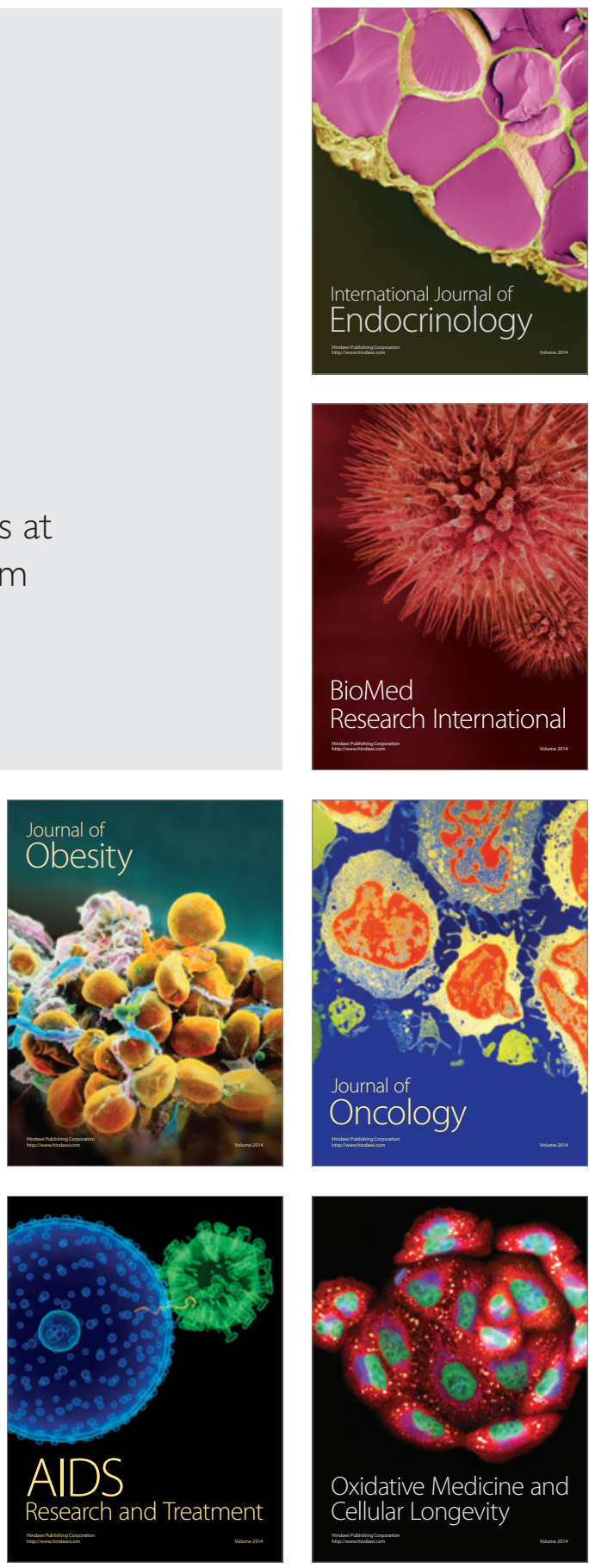